\title{
Time-dependent aggregation of casein micelle concentrates
}

\author{
Pulari Krishnankutty Nair ${ }^{1 *} \dagger$ 당 and Milena Corredig ${ }^{1,2}$ () \\ ${ }^{1}$ Department of Food Science, University of Guelph, Guelph, ON, Canada N1G 2W1 \\ ${ }^{2}$ Food Science, Aarhus University, iFOOD Center, AgroFood Park 48, Aarhus N, 8200 Denmark
}

\begin{abstract}
This research focused on understanding physical and chemical changes occurring to concentrated milk protein suspensions as a function of time. Skim milk (untreated and heat treated at $90^{\circ} \mathrm{C}$ for $10 \mathrm{~min}$ ) was concentrated at 6 times the original volume using osmotic stressing, a noninvasive concentration method, maintaining the serum composition as close as possible to that of native milk. A protease inhibitor cocktail, with broad specificity for the inhibition of serine, cysteine, aspartic proteases, and aminopeptidases, was added in selected samples. Within $9 \mathrm{~d}$ of storage at $4^{\circ} \mathrm{C}$, the apparent viscosity increased markedly for both unheated and heated concentrated milk, but not for those in the presence of protease inhibitors. However, only unheated milk showed a significant increase in the apparent diameter of the casein micelles. Matrixassisted laser desorption-ionization time-of-flight mass spectrometry measurements indicated a significantly lower extent of proteolysis in heated than in unheated samples. The microstructure of the aggregates was observed using field emission scanning electron microscopy, and unheated samples clearly showed aggregation of casein micelles with storage time. In heated samples, aggregation was instead triggered by heat-induced protein-protein interactions.
\end{abstract}

Key words: casein micelle, osmotic stressing, proteolysis, age gelation

\section{INTRODUCTION}

In recent years, the dairy industry has turned its attention toward the use of fresh liquid milk protein concentrates obtained by membrane filtration, as an

Received March 10, 2020.

Accepted August 13, 2020.

*Corresponding author: pulari.nair@danone.com

$\nmid$ Present address: Danone North America, Louisville, CO 80027. ingredient. However, very little is understood about the storage stability of such ingredients. Milk protein concentrates (MPC) are different from milk concentrated by evaporation, where there is no selective concentration. In milk concentrates obtained by UF or nanofiltration, the proteins are selectively concentrated, and if no diafiltration with water is applied during membrane processing conditions, the serum phase composition is similar to that of the original skim milk (Ferrer et al., 2011; Krishnankutty Nair and Corredig, 2015). These concentrates show similar or improved functionality than that of skim milk at lower protein concentrations (Ye, 2011; Luo et al., 2016; Renhe et al., 2019). Fresh MPC are widely used as a protein source in many dairy applications, such as standardization of cheese milk, processed cheese, yogurt, creamers, high protein sports drinks, and other nutritional beverages.

During membrane filtration, solubilization of colloidal calcium phosphate and dissociation of caseins from micelles can be observed (Ye, 2011; Liu et al., 2017). In addition, a noticeable change in the micellar hydration is also shown (Liu et al., 2017). However, most modifications are affected by the processing history of milk during concentration (Corredig et al., 2019).

The changes in viscosity and formation of sediment in milk concentrates with storage have been widely reported (Bienvenue et al., 2003; Datta and Deeth, 2003; Crudden et al., 2005b; Kelly and Fox, 2006; Trinh et al., 2007; Anema, 2018); however, differences in processing history make any comparison between the studies challenging. When using ultrafiltered milk, altered proteolysis and subsequent ripening characteristics due to plasmin activity have been reported for cheese (Benfeldt, 2006).

Much work has been carried out on the effect of proteolysis on the physical and chemical stability of the milk in UHT-treated products, including concentrates (Hinrichs, 2000), and the consequences to their storage stability (Jensen et al., 2015). In this case, in addition of the hydrolysis due to residual proteases, Maillard reactions appear to be one of the major factors affecting quality (Rauh et al., 2015). The storage stability is affected by the ratio of salts or lactose to protein and 
the volume fraction of the proteins and fat globules when the heating process occurs. In this regard, many of the studies have been carried out by heating already concentrated milk suspensions, and this may be quite different from concentrating after heat treatment (Hinrichs, 2000; Rauh et al., 2015). A better understanding of the age gelation of concentrates will allow for better process controls, optimization of resources, and supply chain logistics.

The objective of the present work was to investigate the physico-chemical changes of casein micelles in concentrated suspensions as a function of time. For experimental design, unheated skim milk (i.e., raw skim milk with no inactivation of endogenous proteases) and extensively heat-treated $\left(90^{\circ} \mathrm{C}\right.$ for $\left.10 \mathrm{~min}\right)$ skim milk samples were concentrated further to 6 times their original volume to accelerate possible destabilization effects. To avoid fouling, postprocessing contamination by membrane filtration, and shear effects, the samples were concentrated by osmotic stressing (Bouchoux et al., 2009a,b; Krishnankutty Nair et al., 2013, 2014). This concentration method allows for a careful control of the serum composition, while reaching high protein volume fractions (Krishnankutty Nair and Corredig, 2015). The concentrates, containing 15 to $18 \%$ milk protein, were stored at $4^{\circ} \mathrm{C}$. To inhibit enzyme-mediated proteolysis, a protease inhibitor cocktail, with a broad specificity for the inhibition of serine, cysteine, aspartic proteases, and aminopeptidases, was added to the concentrates. A combination of particle size analysis, MALDI-TOF, field emission scanning electron microscopy, and rheological analysis were used to test the hypothesis that in both heated and unheated concentrates, proteolysis plays a major role in affecting the quality of the concentrates during storage.

\section{MATERIALS AND METHODS}

\section{Skim Milk, Concentrated Milk, and Permeate Preparation}

Fresh milk was obtained from the University of Guelph experimental station (University of Guelph Dairy Research Station, Ponsonby, Ontario, Canada), and sodium azide $(0.2 \mathrm{~g} / \mathrm{L})$ was added to prevent microbial growth. Skim milk was prepared by centrifugation and filtration, as previously described (Krishnankutty Nair et al., 2013). Permeate (milk serum) was prepared by UF of reconstituted skim milk powder (100 g/L solids; Gay Lea Foods Cooperative, Guelph, Ontario, Canada) using a polyethersulfone OPTISEP filter (Smartflow Technologies, Apex, NC, $10 \mathrm{kDa}$ ) at ambient temperature $\left(22^{\circ} \mathrm{C}\right)$.
A portion of the milk was heated for 10 min at $90^{\circ} \mathrm{C}$ in a water bath allowing $2.5 \mathrm{~min}$ for the samples to reach the final temperature before concentration. This temperature-time combination is proven to induce extensive whey protein denaturation and the formation of aggregates in the serum phase (Corredig and Dalgleish, 1996). After heating, the milk samples were immediately cooled to room temperature by immersion in an ice bath, and allowed to equilibrate for $2 \mathrm{~h}$ before concentration.

Milk was concentrated to 6 times the original volume fraction using osmotic stressing (Krishnankutty Nair et al., 2014). Forty milliliters of untreated or heated milk was placed in a dialysis bag and then immersed in a reservoir containing $1 \mathrm{~L}$ of stressing solution composed of $95 \mathrm{~g} / \mathrm{L}$ polyethylene glycol (35,000 Da, Fluka, Oakville, Ontario, Canada) dispersed in milk permeate. The samples were kept in the stressing polymer solution for $18 \mathrm{~h}$ at $4^{\circ} \mathrm{C}$ to obtain $6 \times$ concentrated milk (Krishnankutty Nair et al., 2014).

Selected samples were mixed with a protease inhibitor cocktail (catalog number P 8340, Sigma-Aldrich, St. Louis, MO) suspended in dimethyl sulfoxide. The inhibitor cocktail had a broad specificity for the inhibition of serine, cysteine, aspartic proteases, and aminopeptidases (Sigma P8340; Sigma-Aldrich, 2010), and it contained 4-(2-aminoethyl) benzenesulfonyl fluoride (AEBSF), pepstatin A, E-64, bestatin, leupeptin, and aprotinin. In general, AEBSF inhibits serine proteases (trypsin; EC 3.4.21.4, chymotrypsin; EC 3.4.21.1 and plasmin; EC 3.4.21.7). Pepstatin A is a generic inhibitor for aspartic proteases, such as pepsin (EC 3.4.23.1), chymosin (EC 3.4.23.4), cathepsin D (EC 3.4.23.5), and many microbial aspartic proteases (Shakeel-UrRehman et al., 1998). Similar to AEBSF, aprotinin is a classic member of the Kunitz-type serine protease inhibitors (Sigma P8340; Sigma-Aldrich, 2010). Bestatin is a competitive inhibitor for aminopeptidases (EC 3.4.11), which are categorized under unidentified milk proteases (Kelly et al., 2006). E-64 is an epoxide that can irreversibly inhibit a wide range of cysteine peptidases called cathepsins. Although leupeptin is a widespectrum inhibitor toward cysteine (cathepsin B, EC 3.4.22.1) and serine peptidases, its effect can be suppressed by excess amount of substrate (Sigma-Aldrich, 2010). The inhibitor mixture was added at a 1:100 (vol/ vol) ratio of initial milk. Due to the low molecular size of the inhibitors, the inhibitor mixture was added after concentration to ensure no losses during osmotic stressing. Samples with no inhibitor added had only dimethyl sulfoxide added at the same mix to milk ratio.

All samples were stored at refrigeration temperature $\left(4^{\circ} \mathrm{C}\right)$ for $9 \mathrm{~d}$ before analysis. 


\section{Particle Size Determination by Dynamic Light Scattering}

The particle size of the casein micelles was measured by dynamic light scattering (Zetasizer Nano-ZS, Malvern, Worcestershire, UK) at a scattering angle of $90^{\circ}$. After concentration, the milk samples were diluted $\sim 2,000$ times in filtered $(0.2-\mu \mathrm{m}$ nylon filters, Thermo Fisher Scientific, Mississauga, Ontario, Canada) milk permeate and analyzed in triplicate.

\section{Rheology Measurements}

A controlled stress rheometer (Paar Physica MC 301, Anton Paar, Graz, Austria) was used to measure the viscosity of the concentrate. The milk samples were subjected to a shear sweep test from 0.1 to $300 \mathrm{~s}^{-1}$ using a cone and plate geometry with a set gap of 0.51 $\mathrm{mm}$. The temperature of the plate was controlled with water circulating from a Julabo F25-HP refrigerated and heated water bath (Julabo Labortechnik, GmbH, Seelbach, Germany). All measurements were made at $4^{\circ} \mathrm{C}$.

\section{Analysis of the Serum Phase}

Milk samples were centrifuged at 100,000 $\times g$ for 1 $\mathrm{h}$ at $20^{\circ} \mathrm{C}$ in a Beckman Coulter Optima LE-80K ultracentrifuge with rotor type $70.1 \mathrm{Ti}$ (Beckman Coulter Canada Inc., Mississauga, Canada) to separate the casein micelles from the serum fraction. The supernatant was carefully recovered using a Pasteur pipette, and was given 2 sequential filtrations using $0.45 \mu \mathrm{m}, 0.22$ $\mu \mathrm{m}$ (syringe-driven filters, Thermo Fisher Scientific), and then analyzed for peptides and minerals by reversephase (RP) HPLC and inductively coupled plasma optical emission spectrometry, respectively.

The SDS-PAGE electrophoresis was also performed on all centrifugal supernatants as previously described (Krishnankutty Nair et al., 2014), but no apparent differences were shown in the amount of whey proteins or soluble caseins. Hence, to evaluate changes in hydrolysis, RP-HPLC was performed. The clear filtered supernatant $(20 \mu \mathrm{L})$ was injected into a column (C18 Nova-Pak $4 \mu \mathrm{m}, 3.9 \times 150 \mathrm{~mm}$, Waters, MA) with a C18 guard column (GE Healthcare Life Sciences, Marlborough, MA). The analysis was carried out with a SpectraSystem HPLC (Thermo Fisher Scientific) consisting of a degasser, a P4000 pump, an auto injector (AS3500), and a UV 2000 detector (Thermo Electron Corporation, San Jose, CA). Elution was carried out using $0.01 \mathrm{~g} / \mathrm{L}$ ( $\mathrm{vol} / \mathrm{vol}$ ) trifluoracetic acid containing $0.198 \mathrm{~g} / \mathrm{L}$ acetonitrile for $40 \mathrm{~min}$ followed by a rapid increase (in $1 \mathrm{~min}$ ) to $9.8 \mathrm{~g} / \mathrm{L}$ for $7 \mathrm{~min}$. The area under the peaks detected at $214 \mathrm{~nm}$ was calculated using ChromQuest software (ChromQuest 4.1. Thermo Electron).

Peaks of interest were manually collected and analyzed using MALDI-TOF MS at the Advanced Analysis Centre of the University of Guelph. In addition, mineral composition was determined using inductively coupled plasma optical emission spectrometry at the Laboratory Services facilities of the University of Guelph.

\section{Field Emission Scanning Electron Microscopy}

Scanning electron microscopy was conducted to observe the changes occurring to the structure of the casein micelles during storage. The samples were prepared using a published method (Martin et al., 2006). Briefly, clean and dry polished carbon planchets (Canemco Inc., St. Laurent, Quebec, Canada) were placed in 2 $\mathrm{m} M$ 11-mercapto-undecanoic acid (11-MUA, SigmaAldrich) for $18 \mathrm{~h}$ to form a self-assembled monolayer. The functional groups were then modified using equal volumes of $0.1 M N$-hydroxy succinimide (NHS, Fluka) and 0.4 $M$ 1-ethyl-(3dimethyl aminopropyl) carbodiimide hydrochloride (EDS, Sigma-Aldrich). A few drops of the concentrated milk were then deposited on the polished carbon surface and incubated for $45 \mathrm{~min}$. The planchets were then rinsed with $20 \mathrm{~m} M$ imidazole buffer ( $\mathrm{pH}$ 7.0) containing $5 \mathrm{~m} M$ calcium chloride. The buffer was then exchanged with the fixative, $0.15 \mathrm{~g} / \mathrm{L}$ glutaraldehyde solution for $30 \mathrm{~min}$. The sample was rinsed with Milli-Q water and then dehydrated using a graded ethanol series: 70, 90, and 100\% ethanol before critical point drying using solid carbon dioxide. The samples were then mounted onto scanning electron microscopy stubs with colloidal carbon and stored in a desiccator at room temperature until imaging.

Images were obtained using a Hitachi S4800 FESEM (Field Emission Scanning Electron Microscopy, Tokyo, Japan). Imaging was conducted at Hitachi Canada (Rexdale, Ontario). Acceleration voltage was kept constant at $2.0 \mathrm{kV}$. The samples were not coated. Images were acquired digitally using Quartz PCI software (Vancouver, BC, Canada).

\section{Statistical Analysis}

All experiments were conducted in triplicate (i.e., 3 separate milk batches), and the average and standard errors are reported. Statistical significance of the mean values of the experiment was evaluated using ANOVA at $P<0.05$ using GraphPad Prism software (La Jolla, $\mathrm{CA})$. 
Table 1. Values of apparent viscosity at $200 \mathrm{~s}^{-1}$ and the corresponding changes in viscosity after $9 \mathrm{~d}$ of storage for the freshly concentrated unheated and heated milk, with and without protease inhibitors ${ }^{1}$

\begin{tabular}{lccc}
\hline & & \multicolumn{2}{c}{ Changes in viscosity after $9 \mathrm{~d}$} \\
\cline { 3 - 4 } Item & $\begin{array}{c}\text { Initial viscosity } \\
(\mathrm{Pa} \cdot \mathrm{s})\end{array}$ & No protease inhibitors & Protease inhibitors \\
\hline Unheated & $0.06 \pm 0.02^{\mathrm{a}}$ & $0.052 \pm 0.019^{\mathrm{a}}$ & $0.0 \pm 0.0^{\mathrm{b}}$ \\
Heated & $0.030 \pm 0.002^{\mathrm{a}}$ & $0.036 \pm 0.008^{\mathrm{a}}$ & $0.004 \pm 0.002^{\mathrm{c}}$ \\
\hline
\end{tabular}

${ }^{a-c}$ Different superscript letters indicate statistically significant differences at $P<0.05$ (initial viscosities are considered separately).

${ }^{1}$ The change in viscosity is calculated as the difference between initial viscosity and final viscosity after storage. Values are the average and SD for 3 separate replicates.

\section{RESULTS AND DISCUSSION}

\section{Rheology}

Figure 1 illustrates the apparent viscosity of the concentrate suspensions, heated and unheated, right after concentration and after $9 \mathrm{~d}$ of storage. The values are shown as a function of shear rate to illustrate

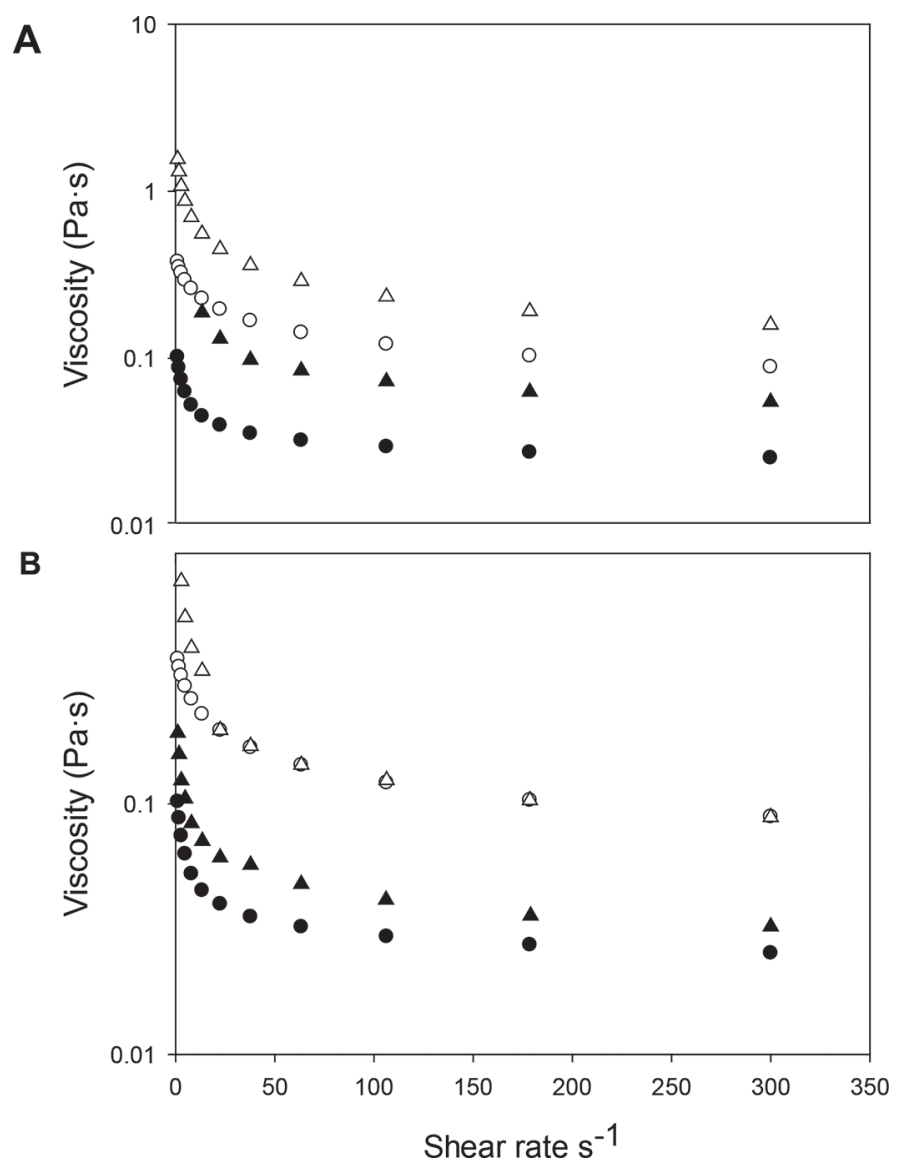

Figure 1. Apparent viscosity as a function of shear rate for unheated (empty symbols) and heated (filled symbols) concentrated milk fresh $(\mathrm{O}, \boldsymbol{\bullet})$ and after $9 \mathrm{~d}$ of storage $(\Delta, \boldsymbol{\Delta})$ without $(\mathrm{A})$ or with $(\mathrm{B})$ protease inhibitor added. their shear thinning behavior, which was typical of $6 \times$ concentrated milk (Snoeren et al., 1984; Vélez-Ruiz and Barbosa-Canovas, 1998; Bienvenue et al., 2003; Trinh et al., 2007). The decrease in apparent viscosity is due to the particle-particle interactions and the realignment of casein micelles in the direction of flow (Vélez-Ruiz and Barbosa-Canovas, 1998). Table 1 summarizes the values of apparent viscosity measured at $200 \mathrm{~s}^{-1}$ for heated and untreated concentrates at $0 \mathrm{~d}$ and the changes in viscosity after $9 \mathrm{~d}$ of storage at $4^{\circ} \mathrm{C}$. There were no significant changes in viscosity measured at $200 \mathrm{~s}^{-1}$ in protein concentrates at $0 \mathrm{~d}$ with heating treatment. After $9 \mathrm{~d}$ of storage, the apparent viscosity of the concentrates doubled in both cases, with no effect of heat treatment. Similar results were reported for concentrated ultrafiltered milk stored at $50^{\circ} \mathrm{C}$ for 4 $\mathrm{h}$ (Bienvenue et al., 2003) or $65^{\circ} \mathrm{C}$ for $100 \mathrm{~min}$ (Trinh et al., 2007). This is significant as a viscosity increase during storage, which is a challenge during processing (Bienvenue et al., 2003).

In the presence of the protease inhibitor mix, concentrated suspensions, both heated and unheated, showed no changes in apparent viscosity. Their flow behavior was fully comparable of that of freshly concentrated samples (Figure 1B and Table 1). However, a significantly viscosity build-up was observed for both heated and unheated concentrated milk samples, in the absence of the protease inhibitor. It is then concluded that proteolysis products played a major role in the aggregation during storage. However, even if protease inhibitors strongly hindered the formation of an aggregate, there were differences between heated and unheated milk due to the presence of heat-induced complexes in serum and their interactions with casein micelles (McMahon, 1995; Datta and Deeth, 2003; Crudden et al., 2005b).

\section{Particle Size}

To determine if the increase in viscosity was also accompanied by the aggregation of the casein micelles, the apparent hydrodynamic diameter of the protein 
particles present in the milk protein concentrated suspensions was measured after extensive dilution in permeate during storage (Figure 2). All fresh skim milk concentrate suspensions showed a similar average diameter of about $165 \pm 0.6 \mathrm{~nm}$. Untreated milk showed a significant increase in the size of the casein micelles with storage time within the first $3 \mathrm{~d}$ of storage. The aggregation was caused by the activity of endogenous proteases, as samples with added inhibitors did not show any change with storage time. Heated skim milk did not show the same behavior. The initial casein micelles diameter was larger than that of control (untreated milk) due to the interaction between the casein micelles and the heat-induced whey protein complexes (Anema and Li, 2003; Vasbinder and de Kruif, 2003). Regardless of the presence of protease inhibitor, there was a slight increase of about $10 \mathrm{~nm}$ of diameter over storage time, perhaps due to additional protein-protein interactions between casein micelles and heat-induced aggregates during storage. These results agree with previous reports (Bienvenue et al., 2003; Trinh et al., 2007), which suggested irreversible aggregation in concentrated milk samples.

The present results demonstrate that at $4^{\circ} \mathrm{C}$, only a slight aggregation occurred in samples heated before concentration. This is fully in line with recent work (Anema, 2017) illustrating that progressive aggregation of casein micelles occurs during storage through intermicellar cross linking of $\kappa$-CN depleted casein micelles. This mechanism ultimately triggers age gelation, which would involve a continuous increase in the size of micelles during storage. However, as shown in Figure 2, the size increase did not correspond to extensive intermicellar aggregation, but rather suggested further association of soluble complexes on the surface of casein micelles. The slight increase in the size of the micelles seemed to plateau after $3 \mathrm{~d}$ of storage. It is important to point out that the apparent diameter of the casein micelles was measured after extensive dilution in milk serum. Statistical analysis of heated samples showed that protease inhibitor had no significant effect, whereas storage time was a significant factor in both cases, with or without inhibitor $(P<0.01)$. We hypothesize that in heat-treated skim milk, after concentration, the increase in the size of the micelles with storage at $4^{\circ} \mathrm{C}$ is due to the contribution of whey protein complexes, which agrees with prior suggestions (Datta and Deeth, 2003; Crudden et al., 2005a). In other words, bridging will occur between $\beta$-LG and $\kappa$-CN heat-induced complexes and the casein micelles, causing aggregation and increase in viscosity. In the present work, SDS-PAGE of the centrifugal supernatants after $9 \mathrm{~d}$ of storage did not show a change in the amount of whey proteins or $\kappa-\mathrm{CN}$

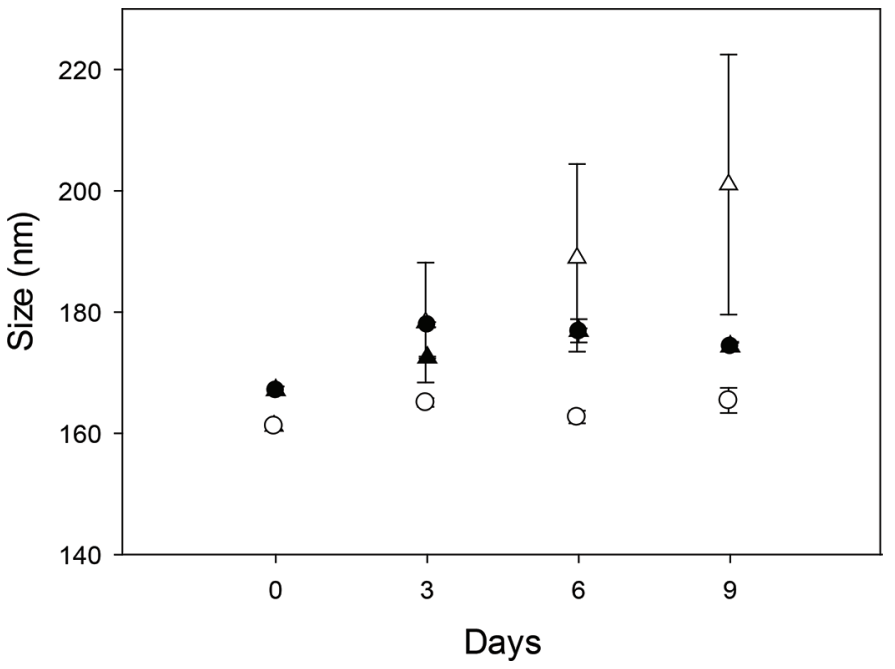

Figure 2. Average apparent diameter of casein micelles in concentrated milk from unheated (empty symbols) and heated (filled symbols) samples with $(O, \bullet)$ or without $(\Delta, \boldsymbol{\Delta})$ protease inhibitor during storage. Values are the average of 3 replicates with SD.

complexes (data not shown), indicating no significant shift in the distribution of the complexes between soluble and associated with the micelles. However, it is possible that the centrifugal conditions caused coprecipitation of the soluble aggregates.

\section{Proteolysis of Protein Concentrate Suspensions}

The presence of proteolysis in the heated and unheated samples was further confirmed using RP-HPLC and MALDI-TOF. The peptide profiles analyzed in the centrifugal supernatants after $9 \mathrm{~d}$ of storage at $4^{\circ} \mathrm{C}$ showed a large presence of proteolysis products in unheated

Table 2. Molecular weight of major peptides estimated using MALDITOF MS from the major fractions eluted from reverse-phase HPLC of the supernatant of unheated milk after $9 \mathrm{~d}$ of refrigerated storage

\begin{tabular}{lc}
\hline $\begin{array}{l}\text { Retention } \\
\text { time (min) }\end{array}$ & Molecular weight (Da) \\
\hline 14.41 & 2,443 \\
& 2,523 \\
14.97 & 2,582 \\
& 2,507 \\
20.12 & 3,234 \\
& 2,424 \\
22.95 & 3,314 \\
& 4,273 \\
& 6,566 \\
& 6,486 \\
24.45 & 6,793 \\
& 13,322 \\
& 8,102 \\
\hline
\end{tabular}


samples, compared with heated. The main peaks eluted from RP-HPLC were analyzed using MALDI-TOF MS to identify the range of molecular weight. Table 2 indicates the signal mass to charge ratio $(\mathrm{m} / \mathrm{z})$ under positive ionization mode for major fractions eluted from
RP-HPLC of the supernatant of unheated milk after $9 \mathrm{~d}$ of refrigerated storage. A combination of mainly small $(2-6 \mathrm{kDa})$ and medium molecular weight peptides $(12 \mathrm{kDa})$ were observed between 14 and $25 \mathrm{~min}$ of retention time. These observations were consistent
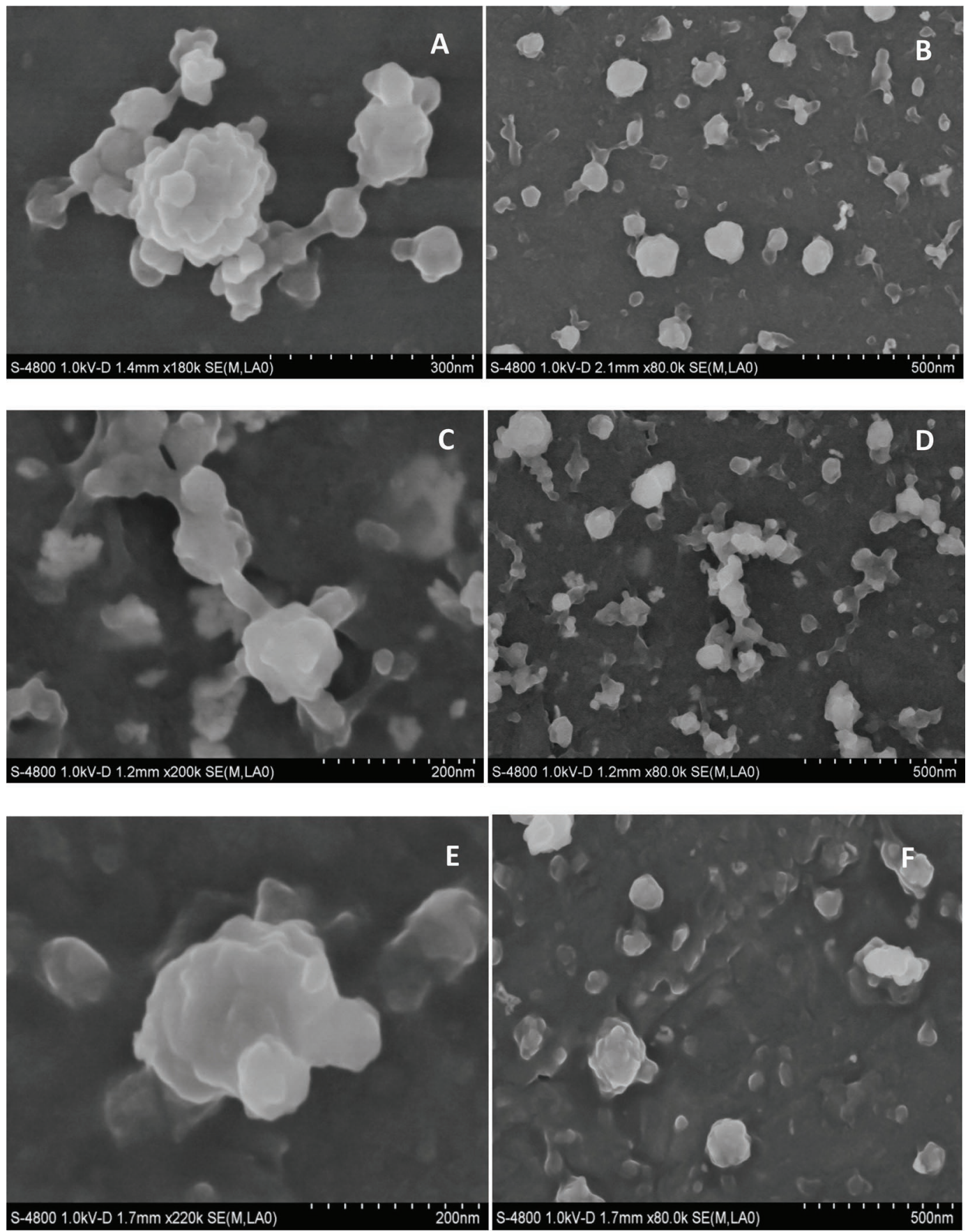

Figure 3. Electron micrograph of the casein micelle of raw concentrated milk at $0 \mathrm{~d}(\mathrm{~A}$ and $\mathrm{B})$ and $9 \mathrm{~d}(\mathrm{C}$ and $\mathrm{D})$ and with protease inhibitor at $9 \mathrm{~d}(\mathrm{E}$ and $\mathrm{F})$ using field emission scanning electron microscopy. The scale bars and accelerating voltage are given in the figure itself. 

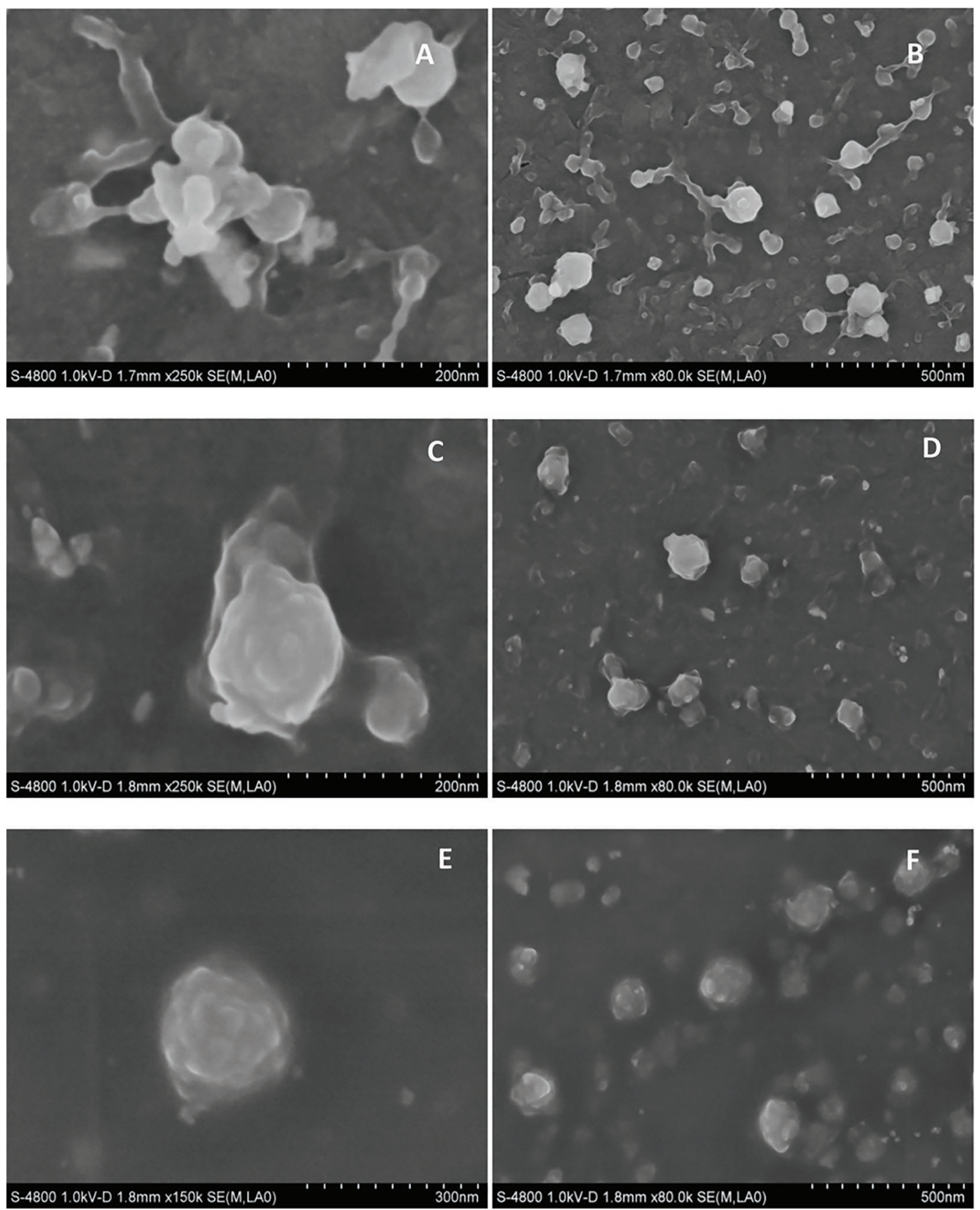

Figure 4. Electron micrograph of the casein micelle of heated concentrated milk at $0 \mathrm{~d}(\mathrm{~A}$ and $\mathrm{B})$ and $9 \mathrm{~d}(\mathrm{C}$ and $\mathrm{D})$ and with protease inhibitor at $9 \mathrm{~d}(\mathrm{E}$ and $\mathrm{F})$ using field emission scanning electron microscopy. The image contains scale bars and accelerating voltage used for the experiment.

with the presence of peptides deriving from caseins, in the range between 12 and $2 \mathrm{kDa}$ (De Noni et al., 2007). In a separate study, small peptides between 2 and 4.4 $\mathrm{kDa}$ were measured in stored UHT milk (Meltretter et al., 2008; D'Incecco et al., 2019). These peptides may be mainly derived from the hydrolysis of $\beta-\mathrm{CN}$ and $\alpha_{\mathrm{S1}^{-}}$
$\mathrm{CN} / \alpha_{\mathrm{S}^{2}} \mathrm{CN}$ (Anema, 2018). This proteolysis affects the colloidal stability of casein micelles, resulting in the aggregation of destabilized casein micelles and hydrolyzed fragments with each other (Anema, 2018).

Unlike for unheated samples, the peptide profile of heated milk concentrates after $9 \mathrm{~d}$ of storage either 
with or without inhibitor cocktail did not yield any significant difference. Other authors reached similar observations (Newstead et al., 2006; Rauh et al., 2014; Anema, 2017), concluding that heat treatments prevented the proteolytic breakdown of caseins by inactivating proteolytic enzymes. The samples were stored only for $9 \mathrm{~d}$. It is important to note that autolysis of plasmin occurs at refrigerated temperatures $\left(\right.$ at $\left.5^{\circ} \mathrm{C}\right)$ as well as little activation of plasminogen (Crudden et al., 2005b). It could be concluded that raw milk contained several heat-labile proteolytic enzymes derived from psychotropic bacteria capable of producing proteolytic enzymes at refrigerated temperatures (D'Incecco et al., 2019).

\section{Field Emission Scanning Electron Microscopy of Casein Micelles}

Field emission scanning electron microscopy images of milk concentrates from unheated milk, fresh milk, and milk after $9 \mathrm{~d}$ of storage, with and without protease inhibitors are shown in Figure 3. These are the representative images of 3 independent trials. The micellar structure was consistent with previous observations using a similar sample preparation protocol (Dalgleish et al., 2004). In general, the individual micelles were spherical in nature. During storage, an increase in extensions was observed, with a tendency for a higher number of connections with neighboring micelles (Figure 3C, D). These extensions might be the polyelectrolyte brush of $\kappa-\mathrm{CN}$ as suggested by many in the literature or could be the complexes of $\kappa-\mathrm{CN}$ and whey protein aggregates (McMahon and McManus, 1998; Dalgleish et al., 2004). These images showing increased protein-protein interactions were consistent with the change in viscosity as well as an increase in the mean micellar diameter of the micelles. The presence of peptide inhibitors seemed to limit the formation of such appendages (Figure $3 \mathrm{E}$ and $\mathrm{F}$ ).

The casein micelles prepared from heated milk concentrates (Figure 4A, B) showed a different morphology compared with those from unheated milk. The heattreated particles showed a rough surface compared with those shown in Figure 4 due to the presence of heatinduced aggregates (Guyomarc'h et al., 2003; Anema, 2017). After $9 \mathrm{~d}$ of storage, the casein micelles appeared to be spherical with no extensions on their surface (Figure $4 \mathrm{C}$ and $\mathrm{D}$ ). The microstructure was similar also in the heated, concentrated milk with protease inhibitors (Figure 4E, F), although there seemed to be a decrease in the scattering contrast of the micelles and the background (Figure 4E, F). This may be due to the presence of heat-induced aggregates in the serum phase. Raynes
Table 3. Ion concentration in the soluble fractions

\begin{tabular}{lccc}
\hline Concentrated milk & $\begin{array}{c}\text { Calcium } \\
(\mathrm{mg} / \mathrm{L})\end{array}$ & $\begin{array}{c}\text { Phosphates } \\
(\mathrm{mg} / \mathrm{L})\end{array}$ & $\begin{array}{c}\text { Sodium } \\
(\mathrm{mg} / \mathrm{L})\end{array}$ \\
\hline Raw milk, 0 d & $415 \pm 15^{\mathrm{a}}$ & $520 \pm 30^{\mathrm{b}}$ & $560 \pm 20^{\mathrm{c}}$ \\
Raw milk, 9 d & $410 \pm 15^{\mathrm{a}}$ & $505 \pm 5.0^{\mathrm{b}}$ & $585 \pm 5.0^{\mathrm{c}}$ \\
Raw milk with PI & $410 \pm 20^{\mathrm{a}}$ & $515 \pm 35^{\mathrm{b}}$ & $585 \pm 45^{\mathrm{c}}$ \\
Heated milk, 0 d $_{\text {Heated milk, 9 d }}^{400 \pm 10^{\mathrm{a}}}$ & $545 \pm 15^{\mathrm{b}}$ & $575 \pm 15^{\mathrm{c}}$ \\
Heated milk with PI & $410 \pm 10^{\mathrm{a}}$ & $565 \pm 5.0^{\mathrm{b}}$ & $585 \pm 5.0^{\mathrm{c}}$ \\
\hline
\end{tabular}

${ }^{a-c}$ Within a column, different superscript letters indicate statistically significant differences at $P<0.05$.

${ }^{1} \mathrm{PI}=$ protease inhibitor.

et al. (2017) reported the presence of amyloid fibril complexes of $\kappa-\mathrm{CN} / \beta-\mathrm{LG}$ in nondairy buffer systems.

\section{Mineral Analysis}

The ionic composition of the soluble phase was measured by analyzing the centrifugal supernatants of the concentrate suspensions from fresh and stored samples and the data are shown in Table 3. In general, there were no significant changes in the ionic concentrations of calcium and phosphate, which is consistent with prior findings (Anema, 2017).

\section{CONCLUSIONS}

For the first time, casein micelle suspensions at high concentrations were observed after refrigerated storage. It was confirmed that the increase in viscosity observed in concentrated systems is due to aggregation of casein micelles, with an obvious increase of their apparent diameter. The presence of residual proteases plays a major role in the aggregation, and microstructural studies demonstrated the presence of fused micelles. The aggregation was halted by the addition of protease inhibitors. In the case of heat-treated milk, even when proteolysis was inhibited, some aggregation still occurred, due to bridging between heat-induced whey protein aggregates and the casein micelles. This work clearly demonstrated the critical role of milk quality in the viscosity build-up of milk concentrates.

\section{ACKNOWLEDGMENTS}

The support of Hitachi Canada (Rexdale, ON, Canada) and the help of Alexandra Smith (University of Guelph, Guelph, ON, Canada) are acknowledged in this work. This work was funded by the Natural Sciences and Engineering Council of Canada (Ottawa, Canada) and the Ontario Dairy Council through the 
Industrial Research Chair program (ON, Canada). The authors have not stated any conflicts of interest.

\section{REFERENCES}

Anema, S. G. 2017. Storage stability and age gelation of reconstituted ultra-high temperature skim milk. Int. Dairy J. 75:56-67. https:// doi.org/10.1016/j.idairyj.2017.06.006.

Anema, S. G. 2018. Age gelation, sedimentation, and creaming in UHT milk: A review. Compr. Rev. Food Sci. Food Saf. 18:12407.

Anema, S. G., and Y. Li. 2003. Effect of pH on the association of denatured whey proteins with casein micelles in heated reconstituted skim milk. J. Agric. Food Chem. 51:1640-1646. https://doi.org/10 $.1021 / \mathrm{jf0} 25673 \mathrm{a}$.

Benfeldt, C. 2006. Ultrafiltration of cheese milk: Effect on plasmin activity and proteolysis during cheese ripening. Int. Dairy J. 16:600608. https://doi.org/10.1016/j.idairyj.2005.10.016.

Bienvenue, A., R. Jimenez-Flores, and H. Singh. 2003. Rheological properties of concentrated skim milk: Importance of soluble minerals in the changes in viscosity during storage. J. Dairy Sci. 86:3813-3821. https://doi.org/10.3168/jds.S0022-0302(03)73988 $-5$.

Bouchoux, A., P. Cayemitte, J. Jardin, G. Gésan-Guiziou, and B. Cabane. 2009a. Casein micelle dispersions under osmotic stress. Biophys. J. 96:693-706. https://doi.org/10.1016/j.bpj.2008.10.006.

Bouchoux, A., B. Debbou, G. Gésan-Guiziou, M. Famelart, J. Doublier, and B. Cabane. 2009b. Rheology and phase behavior of dense casein micelle dispersions. J. Chem. Phys. 131:165106-165111. https://doi.org/10.1063/1.3245956.

Corredig, M., and D. G. Dalgleish. 1996. Effect of temperature and $\mathrm{pH}$ on the interactions of whey proteins with casein micelles in skim milk. Food Res. Int. 29:49-55. https://doi.org/10.1016/0963 -9969(95)00058-5.

Corredig, M., P. Krishnankutty Nair, Y. Li, H. Eshpari, and Z. Zhao. 2019. Invited review: Understanding the behavior of caseins in milk concentrates. J. Dairy Sci. 102:4772-4782. https://doi.org/10 $.3168 /$ jds.2018-15943.

Crudden, A., D. Afoufa-Bastien, P. F. Fox, G. Brisson, and A. L. Kelly. 2005a. Effect of hydrolysis of casein by plasmin on the heat stability of milk. Int. Dairy J. 15:1017-1025. https://doi.org/10 .1016/j.idairyj.2004.11.001.

Crudden, A., P. F. Fox, and A. L. Kelly. 2005b. Factors affecting the hydrolytic action of plasmin in milk. Int. Dairy J. 15:305-313. https://doi.org/10.1016/j.idairyj.2004.08.008.

D'Incecco, P., M. Brasca, V. Rosi, S. Morandi, P. Ferranti, G. Picariello, and L. Pellegrino. 2019. Bacterial proteolysis of casein leading to UHT milk gelation: An applicative study. Food Chem. 292:217-226. https://doi.org/10.1016/j.foodchem.2019.04.066.

Dalgleish, D. G., P. A. Spagnuolo, and D. H. Goff. 2004. A possible structure of the casein micelle based on high-resolution field-emission scanning electron microscopy. Int. Dairy J. 14:1025-1031. https://doi.org/10.1016/j.idairyj.2004.04.008.

Datta, N., and H. C. Deeth. 2003. Diagnosing the cause of proteolysis in UHT milk. Lebensm. Wiss. Technol. 36:173-182. https://doi .org/10.1016/S0023-6438(02)00214-1.

De Noni, I., L. Pellegrino, S. Cattaneo, and P. Resmini. 2007. HPLC of proteose peptones for evaluating ageing of packaged pasteurized milk. Int. Dairy J. 17:12-19. https://doi.org/10.1016/j.idairyj .2005.12.010

Ferrer, M. A., M. Alexander, and M. Corredig. 2011. Does ultrafiltration have a lasting effect on the physico-chemical properties of the casein micelles? Dairy Sci. Technol. 91:151-170. https://doi.org/ 10.1007/s13594-011-0002-0.

Guyomarc'h, F., A. J. R. Law, and D. G. Dalgleish. 2003. Formation of soluble and micelle-bound protein aggregates in heated milk. J. Agric. Food Chem. 51:4652-4660. https://doi.org/10.1021/ jf0211783.

Hinrichs, J. 2000. UHT processed milk concentrates. Lait 80:15-23.
Jensen, S., T. Jansson, N. Eggers, M. R. Clausen, L. B. Larsen, H. B. Jensen, C. Ray, A. Sundgren, H. J. Andersen, and H. C. Bertram. 2015. Storage-induced changes in the sensory characteristics and volatiles of conventional and lactose-hydrolyzed UHT processed milk. Eur. Food Res. Technol. 240:1247-1257. https://doi.org/10 $.1007 / \mathrm{s} 00217-015-2427-9$.

Kelly, A. L., and P. F. Fox. 2006. Indigenous enzymes in milk: A synopsis of future research requirements. Int. Dairy J. 16:707-715. https://doi.org/10.1016/j.idairyj.2005.10.018.

Kelly, A. L., F. O'Flaherty, and P. F. Fox. 2006. Indigenous proteolytic enzymes in milk: A brief overview of the present state of knowledge. Int. Dairy J. 16:563-572. https://doi.org/10.1016/j.idairyj .2005.10.019.

Krishnankutty Nair, P., M. Alexander, D. G. Dalgleish, and M. Corredig. 2014. Physico-chemical properties of casein micelles in unheated skim milk concentrated by osmotic stressing: Interactions and changes in the composition of the serum phase. Food Hydrocoll. 34:46-53. https://doi.org/10.1016/j.foodhyd.2013.01.001.

Krishnankutty Nair, P., and M. Corredig. 2015. Rennet-induced gelation of concentrated milk in the presence of sodium caseinate: Differences between milk concentration using ultrafiltration and osmotic stressing. J. Dairy Sci. 98:27-36.

Krishnankutty Nair, P., D. G. Dalgleish, and M. Corredig. 2013. Colloidal properties of concentrated heated milk. Soft Matter 9:38153824. https://doi.org/10.1039/c2sm27540f.

Liu, D., J. Li, J. Zhang, X. Liu, M. Wang, Y. Hemar, J. M. Regenstein, and P. Zhou. 2017. Effect of partial acidification on the ultrafiltration and diafiltration of skim milk: Physico-chemical properties of the resulting milk protein concentrates. J. Food Eng. 212:55-64. https://doi.org/10.1016/j.jfoodeng.2017.05.019.

Luo, X., T. Vasiljevic, and L. Ramchandran. 2016. Effect of adjusted $\mathrm{pH}$ prior to ultrafiltration of skim milk on membrane performance and physical functionality of milk protein concentrate. J. Dairy Sci. 99:1083-1094. https://doi.org/10.3168/jds.2015-9842.

Martin, A. H., H. D. Goff, A. Smith, and D. G. Dalgleish. 2006. Immobilization of casein micelles for probing their structure and interactions with polysaccharides using scanning electron microscopy (SEM). Food Hydrocoll. 20:817-824. https://doi.org/10.1016/j .foodhyd.2005.08.004.

McMahon, D. 1995. Age gelation of UHT milk: Changes that occur during storage, their effect on shelf life and the mechanism by which age-gelation occurs. Pages 315-326 in Heat Treatments and Alternative Methods. Proceedings of International Dairy Federation Symposium, Brussels, Belgium. International Dairy Federation, Brussels, Belgium.

McMahon, D., and W. McManus. 1998. Rethinking casein micelle structure using electron microscopy. J. Dairy Sci. 81:2985-2993. https://doi.org/10.3168/jds.S0022-0302(98)75862-X.

Meltretter, J., A. Schmidt, A. Humeny, C. Becker, and M. Pischetsrieder. 2008. Analysis of the peptide profile of milk and its changes during thermal treatment and storage. J. Agric. Food Chem. 56:2899-2906. https://doi.org/10.1021/jf073479o.

Newstead, D. F., G. Paterson, S. G. Anema, C. J. Coker, and A. R. Wewala. 2006. Plasmin activity in direct-steam-injection UHTprocessed reconstituted milk: Effects of preheat treatment. Int. Dairy J. 16:573-579. https://doi.org/10.1016/j.idairyj.2005.11 .011 .

Rauh, V. M., L. B. Johansen, M. Bakman, R. Ipsen, M. Paulsson, L. B. Larsen, and M. Hammersh øj. 2015. Protein lactosylation in UHT milk during storage measured by liquid chromatographymass spectrometry and quantification of furosine. Int. J. Dairy Technol. 68:486-494. https://doi.org/10.1111/1471-0307.12265.

Rauh, V. M., A. Sundgren, M. Bakman, R. Ipsen, M. Paulsson, L. B. Larsen, and M. Hammershøj. 2014. Plasmin activity as a possible cause for age gelation in UHT milk produced by direct steam infusion. Int. Dairy J. 38:199-207. https://doi.org/10.1016/j.idairyj .2013.12.007.

Raynes, J. K., L. Day, P. Crepin, M. H. Horrocks, and J. A. Carver. 2017. Coaggregation of $\kappa$-casein and $\beta$-lactoglobulin produces mor- 
phologically distinct amyloid fibrils. Small 13:1603591. https://doi .org/10.1002/smll.201603591.

Renhe, I. R. T., Z. Zhao, and M. Corredig. 2019. A comparison of the heat stability of fresh milk protein concentrates obtained by microfiltration, ultrafiltration and diafiltration. J. Dairy Res. 86:347353. https://doi.org/10.1017/S0022029919000426.

Shakeel-Ur-Rehman, E. P., P. L. H. Feeney, P. F. McSweeney, and Fox.. 1998. Inhibition of residual coagulant in cheese using pepstatin. Int. Dairy J. 8:987-992. https://doi.org/10.1016/S0958 -6946(99)00023-0.

Sigma-Aldrich. 2010. Sigma-Aldrich product information catalogue number P8340. Accessed Jan. 7, 2011. http://www.sigmaaldrich .com/etc/medialib/docs/Sigma/Datasheet/5/p8340dat.Par.0001 .File.tmp/p8340dat.pdf.

Snoeren, T. H. M., J. A. Brinkhuis, A. J. Dammam, and H. J. Klok. 1984. Viscosity and age thickening of skim milk concentrate. Neth. Milk Dairy J. 38:43-53.

Trinh, B., D. Haisman, and K. T. Trinh. 2007. Rheological characterisation of age thickening with special reference to milk con- centrates. J. Dairy Res. 74:106-115. https://doi.org/10.1017/ S0022029906002366.

Vasbinder, A. J., and C. G. de Kruif. 2003. Casein-whey protein interactions in heated milk: The influence of pH. Int. Dairy J. 13:669677. https://doi.org/10.1016/S0958-6946(03)00120-1.

Vélez-Ruiz, J. F., and G. V. Barbosa-Cánovas. 1998. Rheological properties of concentrated milk as a function of concentration, temperature and storage time. J. Food Eng. 35:177-190. https://doi .org/10.1016/S0260-8774(98)00019-3.

Ye, A. 2011. Functional properties of milk protein concentrates: Emulsifying properties, adsorption and stability of emulsions. Int. Dairy J. 21:14-20. https://doi.org/10.1016/j.idairyj.2010.07.005.

\section{ORCIDS}

Pulari Krishnankutty Nair @ https://orcid.org/0000-0001-7299-2043 Milena Corredig (ㄴ) https://orcid.org/0000-0002-9036-8866 